\title{
PIOTR KOPROWSKI
}

Uniwersytet Gdański w Gdańsku

piotr.koprowski@ug.edu.pl

ORCID: orcid.org/0000-0002-3843-3640

\section{HANDEL I JEGO ROLA CYWILIZACYJNA W UJĘCIU JÓZEFA SUPIŃSKIEGO}

\author{
DOI: http://dx.doi.org/10.12775/SPLP.2021.008
}

\section{Streszczenie}

Józef Supiński (1804-1893), polski naukowiec, ekonomista, filozof, socjolog, w obrębie stworzonej w drugiej połowie XIX wieku teorii społeczno-ekonomicznej, uwypuklił kwestie związane z handlem, postrzeganym w kontekście cywilizacyjnym. W artykule przybliżono ich istotę i specyfikę. Supiński podkreślał cywilizacyjną rolę handlu, jego korzystny wpływ na wzrost wielkości produkcji i kapitału społecznego. Handel, będąc w pełni ludzkim tworem, humanizuje relacje społeczne, ogranicza różne formy przemocy, umożliwia pokojowe współistnienie. Jest także spoiwem łączącym jednostki w strukturę społeczeństwa.

Słowa kluczowe: człowiek, handel, cywilizacyjna rola handlu, pokojowe wspótistnienie, przemoc, konkurencja, przyroda

\section{TRADE AND ITS CIVILIZATION ROLE AS PERCEIVED BY JÓZEF SUPIŃSKI}

\begin{abstract}
Józef Supiński (1804-1893), Polish scientist, economist, philosopher, sociologist within the socio-economic theory created in the second half of the 19th century highlighted issues related to trade, perceived in the context of civilization. The article presents their essence and specificity. Supiński emphasized the civilization role of trade, its beneficial influence on the increase in production and social
\end{abstract}


capital. Trade, being a fully human creation, humanizes social relations, limits various forms of violence, and enables peaceful coexistence. It is also the glue that binds individuals together into the fabric of society.

Keywords: human, trade, the civilization role of trade, peaceful coexistence, violence, competition, nature

Józef Supiński (1804-1893), polski naukowiec, ekonomista, filozof, socjolog, jest mniej znaną postacią rodzimego życia umysłowego w XIX wieku. Absolwent Wydziału Prawa i Administracji Uniwersytetu Warszawskiego, następnie uczestnik powstania listopadowego, po jego klęsce udał się na emigrację do Francji, gdzie objął stanowisko dyrektora przędzalni w Paryżu. Chcąc pracować na rzecz polskiego społeczeństwa, osiedlił się w 1844 roku we Lwowie, gdzie dzięki protekcji księcia Leona Ludwika Sapiehy (1803-1878) otrzymał początkowo posadę w Towarzystwie Kredytowym Ziemskim, a później w Kasie Oszczędności ${ }^{1}$. We Lwowie ukazały się również najważniejsze dzieła Supińskiego: Myśl ogólna fizjologii wszechświata (1860) oraz Szkoła polska gospodarstwa społecznego (1862-1865). Autor zawarł w nich własną teorię społeczno-ekonomiczną, w obrębie której istotne miejsce zajmują kwestie związane $\mathrm{z}$ handlem, postrzeganym w kontekście cywilizacyjnym. Celem artykułu jest przybliżenie istoty i specyfiki tychże kwestii.

Supiński wyszedł z założenia, że istnieje ścisły związek między prawami rozwoju życia ekonomicznego a prawami przyrody. Stworzył dosyć zwartą teorię społeczno-ekonomiczną, którą określał mianem „,izyki społecznej” albo „,izjologii wszechświata". Określenia te wskazują na preferowany przezeń mechanistyczny sposób interpretacji fenomenu świata ludzi i natury ${ }^{2}$. Za naczelne prawo wszechświata ekonomista uznał grawitację (prawo powszechnego ciążenia). W działaniu grawitacji dostrzegł proces ścierania się dwóch przeciwstawnych, wprawiających materię w ruch sił: siły wewnętrznej i siły zewnętrznej. Siła wewnętrzna odzwierciedla samoistnienie, rzut, pęd indywidualny, zaś zewnętrzna wiąże się z przyciąganiem i rozkładem ${ }^{3}$.

Człowiek jest - w przeświadczeniu Supińskiego - co prawda cząstką świata przyrody, lecz zarazem wyróżnia się on spośród grona istot organicznych umiejętnością tworzenia nowych wartości. Posługując się pracą i wiedzą, podejmuje

B. Skarga, Józef Supiński i jego filozofia „,miary”, w: Polska myśl filozoficzna i społeczna, pod red. A. Walickiego, t. 1, 1831-1863, Książka i Wiedza, Warszawa 1973, s. 629-630.

2 H. Hołda-Róziewicz, Jednostka w teorii socjologicznej Józefa Supińskiego, „Kwartalnik Historii Nauki i Techniki" 1994, R. 39, nr 1, s. 47.

3 Pisma Józefa Supińskiego, wydał J. Welichowski, t. 1, Drukarnia Zakładu Narodowego im. Ossolińskich, Lwów 1872, s. 81-82, 102-103, 114-122. 
działania wyzwalające go z więzów natury. Rezultatem tych działań jest powstanie w obrębie przyrody świata człowieka, świata, który konstytuuje zasób wiedzy i pracy.

Supiński określił świat człowieka mianem zasobu społecznego, podkreślając zarazem, iż pojęcie to jest - w jego przekonaniu - bardziej precyzyjne od charakteryzującego się wieloznacznością terminu „kapitał”' Nie bez znaczenia jest też fakt, że dla ekonomisty, będącego zwolennikiem ewolucyjnej drogi rozwoju społeczeństwa, kategoria kapitału oznaczała pejoratywne, wąskie zmonopolizowanie przez jedną klasę społeczną narzędzi pracy. Z kolei kategoria zasobu społecznego jest znacznie szersza, obejmując, zdaniem Supińskiego, zarówno wartości materialne, jak i intelektualne, a więc - innymi słowy - dobra przyczyniające się do wzrostu produkcji oraz do dzieła cywilizacji, kształcące intelekt człowieka i uprzyjemniające jego życie. Ekonomista wskazywał przy tym na podrzędną, ale niezbędną rolę materii w procesie tworzenia nowych wartości ${ }^{6}$.

Pochodną tezy o podrzędnej roli materii jest m. in. dokonany przez autora Myśli ogólnej fizjologii wszechświata podział czynników wzrostu bogactwa społecznego na statyczne i dynamiczne. Statyczne czynniki produkcji stanowią ziemia i mieszkająca na niej ludność. Mają one określony wpływ na rozwój gospodarczy, jawiąc się jako niezbędne w procesie tworzenia się zasobów ludzkiej pracy i wiedzy. Z kolei dynamicznymi czynnikami tworzącymi bogactwo społeczne są zasób społeczny i praca. Supiński uwypuklał czynną rolę jednostki ludzkiej w zakresie pracy nad wytworami warunkującymi postęp cywilizacyjny?

Za czynnik decydujący o poziomie wydajności pracy ekonomista uważał wielkość zasobu społecznego, czyli nagromadzonej dzięki wysiłkowi minionych pokoleń wiedzy i umiejętności, którymi człowiek posługuje się w toku procesu produkcji. Tego rodzaju pogląd był następstwem żywionego przez Supińskiego przeświadczenia, iż rezultaty działalności człowieka uzależnione są od wcześniej osiągniętych efektów. W jego myśli mamy - innymi słowy - do czynienia z pierwszeństwem zasobu społecznego przed pracą̧. Dodać trzeba jednak, że w tym kontekście autor Szkoły polskiej gospodarstwa społecznego dowartościował również handel.

4 Tamże, s. 134-138, 142-143, 150-152, 197; R. Torchalski, Józef Supiński-polski teoretyk pracy, „Studia i Materiały z Dziejów Nauki Polskiej” 1973, z. 5, s. 258-274.

5 Pisma Józefa Supińskiego, wydał J. Welichowski, t. 2, Drukarnia Zakładu Narodowego im. Ossolińskich, Lwów 1872, s. 156-157.

6 Pisma Józefa Supińskiego, t. 4, Gebethner i Wolff, Warszawa 1883, s. 7-8.

7 Pisma Józefa Supińskiego, t. 2, dz. cyt., s. 58-59, 87.

8 Józefa Supińskiego pojęcie zasobu społecznego można również analizować w kategoriach kulturowych, jako interesującą koncepcję kultury. Zob. A. Kłoskowska, Socjologia w Polsce w drugiej połowie XIX w., „Studia i Materiały z Dziejów Nauki Polskiej” 1966, z. 9, s. 201. 
W ujęciu Supińskiego ekonomię, czyli naukę gospodarstwa społecznego, współtworzą dwie nauki: praca i handel ${ }^{9}$. Uwypuklił on przede wszystkim dobroczynny wpływ handlu na wzrost skali produkcji i bogactwa społecznego. Wskazał na rolę, jaką spełnił w powstaniu społeczeństwa impuls zewnętrzny: trwoga (uczucie wspólne ludziom i zwierzętom) i religia. Stał jednak na stanowisku, że trwałą więź społeczną zrodził dopiero handel.

Handel pojawił się na określonym szczeblu rozwoju ludzkości jako rezultat określonego zaawansowania procesów społecznych. Stał się znaczącym elementem równowagi między prawami człowieka a jego obowiązkami. O ile w przyrodzie ogół stanów biernych jest równy ogółowi stanów czynnych, o tyle osiągnięcie tego rodzaju równowagi w świecie ludzkim, niezbędne dla prawidłowego funkcjonowania jednostek i społeczeństwa, jest znacznie trudniejsze, nie zawsze w pełni możliwe, a przy tym wymaga dłuższego czasu ${ }^{10}$.

Pierwsze kontakty międzyludzkie nie miały, zdaniem uczonego, na ogół charakteru pokojowego. Ze względu na pierwotny, twardy charakter środowiska przyrodniczego i trud związany z wykonywaniem pracy niemało było w początkowym okresie istnienia ludzkości różnego rodzaju napadów, rozbojów, przywłaszczeń dóbr jednych społeczności przez inne. Tego rodzaju praktyki musiały jednak się zakończyć. Człowiek, będąc istotą rozumną, miał bowiem świadomość niewygód, trudności i niebezpieczeństw związanych z niepokojowymi sposobami zabezpieczania własnych, ciągle rosnących, potrzeb. Za pośrednictwem handlu wszedł więc w kolejny, w większym stopniu bezkrwawy, etap rozwoju społeczno-cywilizacyjnego ${ }^{11}$.

Handel to zjawisko niebędące - w przeświadczeniu Supińskiego - wyrazem siły i specyfiki przyrody. Skłonność doń nie jest też wrodzonym przymiotem jednostki ludzkiej. Człowiek uświadomił sobie pozytywne następstwa handlu na drodze własnych doświadczeń i refleksji. Handel jest „wyrobem jego uczucia, sądu i woli, (...) płodem jego wiedzy”12. Ów typ aktywności stanowi swoisty pomost, łączący zjawiska charakterystyczne dla świata przyrody z tym, co jest właściwe dla świata ludzkiego. Jej przedmiotem nie są dobra występujące w obrębie natury, lecz efekty wiedzy i pracy człowieka.

Według ekonomisty, nie od razu jednak, pomimo rozwoju handlu, udało się wyeliminować napady i rozboje. Obydwie formy kontaktów między ludźmi: pokojowa i niepokojowa występowały równocześnie, przez długi jeszcze czas, wzajemnie sobie towarzysząc. Handel preferowały jednostki i społeczności słab-

9 Pisma Józefa Supińskiego, t. 2, dz. cyt., s. 24; L. Leońska, Józefa Supińskiego teoria gospodarstwa społecznego, „Studia Socjologiczne” 1984, nr 1, s. 271-283.

10 Pisma Józefa Supińskiego, t. 1, dz. cyt., s. 174-177.

11 Tamże, s. 185-187; Pisma Józefa Supińskiego, t. 2, dz. cyt., s. 345-346.

12 Pisma Józefa Supińskiego, t. 1, dz. cyt., s. 187-188. 
sze, widząc w nim sposób realizacji zasad sprawiedliwości społecznej. Z kolei możni i potężni, siłą narzucający swoją wolę, nierzadko pogardzali handlem.

Przemoc leży, zdaniem Supińskiego, w pierwotnej naturze człowieka. Handel zaś ludzkość niejako narzuciła sama sobie. Potwierdzeniem tej tezy są m.in. relacje między białymi kolonistami a Indianami i niewolnikami w Ameryce Północnej. Biali z jednej strony szermowali ideą praw człowieka, z drugiej zaś - gnębili czarnoskórych poddanych i represjonowali społeczności indiańskie.

Dwa aspekty międzyludzkich relacji: przemoc i pokojowe współistnienie znajdują - w przekonaniu autora Szkoły polskiej gospodarstwa spotecznego - wyraz zarówno w toczonych wojnach, jak i w zawieranych przez kraje cywilizowane traktatach pokojowych. Wśród ludności tych krajów często odzywa się, mimo zewnętrznej ogłady i szacunku dla wiedzy, zwierzęca strona ludzkiej natury. Stąd też pojawiają się rozboje, kradzieże, zdrady, oszustwa, przekupstwa i inne podłości. Różnorodność tych godnych potępienia postaw związana jest w dużej mierze z piastowanym stanowiskiem i wykształceniem sprawców. Nie można - podkreślał Supiński - zapominać o tym, że działalność handlowa jako katalizator negatywnych zachowań, czynów i zarazem ucieleśnienie bezpieczeństwa, sprawiedliwości, wolności, to pewien wzorzec, ideał, do którego ludzkość dąży od dawna, lecz dotychczas jeszcze nie w pełni go osiągnęła ${ }^{13}$.

Handel nie tylko przyczynia się do humanizacji relacji międzyludzkich. Odgrywa także ważną rolę w procesie rozwoju produkcji. Skłania producentów do maksymalizacji wartości użytkowych i zmniejszania nakładów pracy. Za sprawą handlu - podkreślał ekonomista - darmowe dobra przyrody znajdują zastosowanie w procesach produkcyjnych, a następnie jako produkty materialne trafiają do rąk nabywców. Nie bez znaczenia jest też fakt, że dzięki niemu następuje sukcesywne zmniejszanie zakresu przemocy w świecie człowieka i zaszczepianie w nim praw przyrodniczych, zwłaszcza prawa równowagi między stanem czynnym i biernym. To ostatnie prawo na gruncie ludzkim, społecznym, przybiera, zdaniem socjologa, postać zasady równowagi praw i obowiązków ${ }^{14}$.

W początkowym okresie dziejów ludzkości pojawiała się - według Supińskiego - jedynie chęć nabycia czegoś, nierekompensowana w ogóle przez chęć zbycia określonego przedmiotu. Przemoc i zabór jako sposób nabywania dóbr sprawiały, że niektórzy ludzie znajdowali się w stanie czynnym, a inni pozostawali w stanie biernym. Tym pierwszym przypadały zaszczyty i prawa, a drudzy musieli tylko wypełniać określone obowiązki. Handel przeobraził w określonym stopniu realną rzeczywistość, stając się ,granicą, chorągwią i kamieniem węgielnym społecznej budowy"15.

13 Tamże, s. 188-190.

14 Tamże, s. 191-193.

15 Pisma Józefa Supińskiego, t. 2, dz. cyt., s. 345. 
Handel umożliwił, zdaniem Supińskiego, narastanie zasobu społecznego, który jest trwałą więzią społeczną i kreatorem autonomii ludzkiej rzeczywistości w obrębie świata przyrody. Działalność handlowa pozwala przekazywać nagromadzone wartości oraz je potęgować. Za jej pośrednictwem człowiek, tworząc zasoby pracy i wiedzy, współpracuje z innymi ludźmi, wyzyskując ich umiejętności i doświadczenia. W efekcie krystalizuje się określony zbiór wartości społecznych i ,zapas użyteczności" ${ }^{\prime \prime}$. Ich narastanie warunkuje dalszy wzrost produkcji dóbr materialnych oraz rozwój nauki i oświaty. Dokonuje się więc - innymi słowy - wyraźny postęp cywilizacyjny.

Handel jest - w przeświadczeniu socjologa - naturalnym spoiwem, łączącym jednostki w organizm społeczny. Jednostki mogą zarazem zachować w ramach społeczeństwa własną odrębność i tożsamość ${ }^{17}$. Handel w połączeniu z pracą kierowaną wiedzą współtworzył naukę gospodarstwa społecznego, zaś jego dzieje to - w koncepcji Supińskiego - de facto dzieje ludzkiego świata, aczkolwiek jeszcze z licznymi reliktami rzeczywistości fizycznej ${ }^{18}$. Wyrazem owych pozostałości jest chociażby przeświadczenie, iż osiągnięty na drodze działalności handlowej zysk jednej strony jest równoznaczny ze stratą drugiej. Ma więc miejsce innymi słowy - przejście własności z rąk do rąk ${ }^{19}$.

Przechodzenie wyrobów z rąk do rąk Supiński uzasadnił wskazując, że następuje $-z$ jednej strony - przekształcanie jeszcze nie w pełni przetworzonej materii, z drugiej zaś - przemieszczanie materii w przestrzeni do miejsc, w których nie ma danych towarów. W związku z tym ekonomista wyróżnił trzy typy handlu: czynny, bierny i obojętny. $Z$ handlem czynnym mamy do czynienia wówczas, kiedy wyroby docierają do miejsc, gdzie staną się przedmiotem dalszego przetwarzania. W tym przypadku zwiększa się rzeczywista wartość tychże wyrobów. Handel jest bierny, jeżeli pobudza zbytek i stanowi zachętę do próżnowania, powodując w efekcie bezproduktywne zużycie dóbr. Mówiąc z kolei o handlu obojętnym, trzeba pamiętać, że wartość przechodzi z rąk do rąk z korzyścią dla jednych i stratą dla drugich. Charakterystyczne są pod tym względem operacje przeprowadzane na giełdach towarowych i pieniężnych ${ }^{20}$.

W wyniku rozwoju handlu korzyści odnoszą obydwie biorące w nim udział strony: sprzedawcy i nabywcy. Potwierdza to - w przekonaniu Supińskiego - nieustannie powiększający się zasób społeczny w krajach zaawansowanych w rozwoju cywilizacyjnym. Źródeł owego postępu nie można upatrywać tylko w fakcie wyzysku przez te kraje zacofanych pod względem gospodarczym obszarów świata.

6 Tamże, s. 140.

17 Pisma Józefa Supińskiego, t. 1, dz. cyt., s. 158-160.

18 Pisma Józefa Supińskiego, t. 2, dz. cyt., s. 346-347.

19 Tamże, s. 347-348.

20 Tamże, s. 348-350; por. A. Cieszkowski, O kredycie i obiegu, Drukarnia: „Praca” J. Leitgeber, Poznań 1911, s. 7. 
Niezwykle ważna przyczyna postępu cywilizacyjnego tkwi w dynamicznie rozwijającym się handlu. Gdyby nie było tego ostatniego, nie zaistniałyby w pełni takie elementy współkonstytuujące postęp, jak: pracowitość i oszczędność mieszkańców, wewnętrzny i międzynarodowy podział pracy, wzrost poziomu wykształcenia specjalistycznego (zawodowego) oraz ogólnego ${ }^{21}$.

Jeśli handel odbywa się bez przeszkód, przynosi powszechne korzyści. Ułatwia nie tylko integrację ludzi w obrębie określonej społeczności, lecz również zespolenie wszystkich narodów w jedną ludzką rodzinę, w jeden ludzki świat. Supiński akcentował w kontekście handlu motyw narodowy. Podkreślał, że w rezultacie działalności handlowej łatwiej „skojarzyć” naród w strukturę narodową 22 . Wskazał ponadto na doniosłą rolę czynników ułatwiających cywilizacyjną misję handlu, wśród których najistotniejsze są: wolność i gwarancja swobodnego rozwoju działań na polu gospodarczym, rozwinięta infrastruktura komunikacyjna (drogi, spławne rzeki, sprawnie funkcjonująca poczta i łączność telegraficzna) oraz system pieniężno-kredytowy ${ }^{23}$.

Interesujące są również uwagi Supińskiego odnoszące się do pieniądza w kontekście handlu. Ekonomista stał na stanowisku, że pieniądz nie jest celem handlu, lecz środkiem służącym do przeprowadzania operacji handlowych. Ilość pieniądza w obiegu jest regulatorem handlu, zwłaszcza zagranicznego ${ }^{24}$. Pieniądz pełni również rolę miernika nakładów człowieka. Objętość, długość i wagę dóbr materialnych można, zdaniem autora Szkoły polskiej gospodarstwa społecznego, zmierzyć za pomocą miar fizycznych. Zawartej w tychże dobrach wartości społecznej, czyli nakładu ludzkiej wiedzy i pracy, nie uda się oznaczyć zmysłowo. Wyzyskać można jednak w tym celu pieniądz, który będzie pełnić funkcję pośredniczącą. Pieniądze - użył obrazowego porównania Supiński - są wozami przewożącymi wartości społeczne, a w przypadku, kiedy „wozów jest za wiele, pójdą one na pół obciążone, lub część ich stać będzie bezczynną"25.

Z handlem związany jest ponadto kredyt, który Supiński zdefiniował jako przekształcenie wartości nieruchomych w obiegowe ${ }^{26}$. Ekonomista wiązał kredyt z nieukończoną, tylko częściowo sfinalizowaną formą handlu, w której zbycie i nabycie określonego dobra nie następuje jednocześnie (zbycie poprzedza nabycie). Podkreślił, że kredyt pojawił się w określonym, już zaawansowanym etapie rozwoju handlu i zarazem sfery cywilizacyjno-oświatowej. Wyróżnił dwa zasadnicze rodzaje kredytu: kredyt publiczny krajowy i międzynarodowy, uznając je za

${ }^{21}$ Pisma Józefa Supińskiego, t. 2, dz. cyt., s. 350-351.

22 A. Lityńska, Idea narodowa i problem więzi społecznej w pracach Fryderyka Skarbka i Józefa Supińskiego, „Zeszyty Naukowe Akademii Ekonomicznej w Krakowie” 2003, nr 594, s. 105-108.

23 Pisma Józefa Supińskiego, t. 2, dz. cyt., s. 351.

24 Tamże, s. 361-362.

25 Tamże, s. 356.

26 Tamże, s. 418,421. 
najwyższe szczeble handlu i ważne determinanty złożonych procesów gospodar$\mathrm{czych}^{27}$.

Korzyści wynikające z istnienia systemu kredytowego są, zdaniem Supińskiego, szczególnie widoczne w przypadku kas oszczędnościowo-pożyczkowych. Te ostatnie mają, oprócz wymiaru ekonomicznego, również wymiar moralny. Przyczyniają się bowiem do wzrostu morale polskiego ludu, motywując go do bardziej efektywnej pracy, powściągania negatywnych skłonności i bycia oszczędnym ${ }^{28}$. Nie bez znaczenia jest też fakt, iż dzięki kredytowi może nastąpić uruchomienie potencjału inicjatywy gospodarczej, tkwiącego w wykształconych i przedsiębiorczych jednostkach, ale ze względu na niedostatek posiadanych przez nie zasobów materialnych niemogących być w pełni społecznie użytecznymi. Kredyt przyczynia się ponadto do poszerzenia rynków zbytu, czyniąc produkty dostępniejszymi dla uboższych warstw ludności. W efekcie różnice dzielące zamożne i niezamożne klasy społeczne zostają w pewnym stopniu zniwelowane, a naród staje się bardziej zwartą całością 29 .

Supiński, co warto podkreślić, przestrzegał przed zaciąganiem kredytów na cele konsumpcyjne, wskazując, że w realiach zacofanych ziem polskich, niedysponujących dostateczną ilością zasobów kapitałowych, prowadziłyby one do roztrwonienia nagromadzonych, nielicznych bogactw i pogłębiłyby regres cywilizacyjny $^{30}$.

Zjawiskiem nieodłącznie towarzyszącym handlowi jest - w przeświadczeniu Supińskiego - „współubieganie”, czyli konkurencja. Ekonomia klasyczna, począwszy od Adama Smitha (1723-1790), dostrzegała w wolnej konkurencji mechanizm zapewniający gospodarce możliwości równomiernego rozwoju ${ }^{31}$. Stworzony przez polskiego ekonomistę model wolnej konkurencji jest modelem konkurencji społeczeństwa obywatelskiego, stojącego na wysokim poziomie oświaty i zamożności, szanującego prawa wszystkich jednostek. Tak rozumiana konkurencja obejmuje całe społeczeństwo, nastawiając się na efektywne wyzyskanie jego potencjału wytwórczego. „Współubieganie społeczne” - podkreślał Supiński - „nie tamuje usiłowań niczyich; (...) nie zagradza nikomu drogi stojącej otworem dla wszyst-

27 Tamże, s. 422-423.

28 Józef Supiński nawiązywał do poglądów ekonomisty, historyka Fryderyka Skarbka (1792-1866), który w rozbudowie „kas zasiłku i oszczędzania” dostrzegał gwarancję poprawy bytu ekonomicznego robotników i chłopów, a także zmianę mentalności tych grup społecznych, prowadzącą w stronę drobnomieszczańskiej oszczędności. J. Górski, Polska myśl ekonomiczna a rozwój gospodarczy 1807-1830. Studia nad początkiem teorii zacofania gospodarczego, Państwowe Wydawnictwo Naukowe, Warszawa 1963, s. 164-165.

29 Pisma Józefa Supińskiego, t. 2, dz. cyt., s. 429-430.

30 Tamże, s. 431.

31 G. Sorman, Nowe bogactwo narodów, Kurs, Łódź-Warszawa 1989. 
kich"32. Dzieje się tak dlatego, iż w myśli socjologa, celem działalności człowieka jest dążenie do służenia innym, a nie wchodzenie na drogę konfliktów społecznych.

Model konkurencji, w którym nie ma walki między dwiema przeciwstawnymi stronami uczestniczącymi w handlu jest, zdaniem Supińskiego, obecny w wysoko rozwiniętych krajach Europy Zachodniej. W tych ostatnich konkurencja nie narusza prawa własności, będąc „wyścigiem rzędów przeciw rzędom”, czyli jednych grup istot organicznych przeciw drugim ${ }^{33}$. Konkurencja jako prawo rynku przyczynia się - obok podaży i popytu - również do braku ogólnej nadprodukcji. Jeśli w Europie pojawiają się niekiedy kryzysy nadprodukcji, to - w przekonaniu ekonomisty - mają one charakter krótkotrwały i są następstwem polityki protekcjonistycznej, stosowanej wobec niektórych gałęzi przemysłu. Nie sposób uwierzyć w możliwość stałej nadprodukcji, gdyż ,kto wyrabia, ten chce zbyć, by nabyć co innego; kto chce nabyć, ten musi wyrabiać" ${ }^{34}$.

„Wyścigi wewnętrzne” między różnymi podmiotami partycypującymi w sferze handlu w czasach szybko narastającego zasobu społecznego owocują pozytywnymi następstwami. W ich wyniku ceny kształtujące się na rynku wahają się wokół ceny uśrednionej, równoważącej popyt z podażą. Nie oznacza to jednak, iż nie występuje wahanie cen.

Wahanie cen jest zjawiskiem, u podłoża którego leży, zdaniem Supińskiego, kilka przyczyn. Znaczącą rolę odgrywa brak pełnej informacji o wielkości produkcji danego wyrobu w skali globalnej oraz niemożność wcześniejszego poznania przez producentów preferencji nabywców. W efekcie decyzje produkcyjne odnośnie do ilości i asortymentu wyrobów zapadają w dużej mierze „na oślep”, w oparciu tylko o zakres aktualnego popytu. Prowadzi to do „wyścigów” między nabywcami i sprzedawcami oraz do „ujemnej” bądź „dodatniej” oscylacji cen rynkowych w stosunku do ceny średniej.

Na wahania cen ma oprócz tego wpływ zróżnicowany stopień wdrożenia odkryć naukowych i wynalazków technicznych w poszczególnych krajach oraz ograniczoność zasobów naturalnych, determinująca możliwości działania człowieka ${ }^{35}$.

Według Supińskiego, ci producenci, którzy pozostają przy tradycyjnych, starych metodach wytwarzania, wcześniej czy później przestają być konkurencyjni i wypadają z rynku. Z kolei w obrębie producentów stosujących nowoczesne techniki produkcji pojawia się „wewnętrzne współubieganie”, czyli rywalizacja. Dzięki temu ceny wyrobów obniżają się. Tendencja obniżania się cen trwa - w przekonaniu ekonomisty - do momentu, kiedy korzyści osiągane przez producentów staną się rzetelnym wynagrodzeniem ich pracy, odpowiadającym wartości spo-

Pisma Józefa Supińskiego, t. 2, dz. cyt., s. 366.

33 Tamże, s. 367.

34 Tamże, s. 368.

35 Tamże, s. 372. 
łecznej ${ }^{36}$. Ta ostatnia kategoria powstaje w procesie produkcji, a na jej wysokość nie ma wpływu istniejąca na rynku konkurencja.

Józef Supiński podkreślił cywilizacyjną rolę handlu, jego korzystny wpływ na wzrost wielkości produkcji i kapitału społecznego. Handel, będąc w pełni ludzkim tworem, humanizuje relacje społeczne, ogranicza różne formy przemocy, umożliwia pokojowe współistnienie. Jest także spoiwem łączącym jednostki w strukturę społeczeństwa. Ekonomista generalnie opowiadał się za liberalizmem w handlu, zarówno wewnętrznym, jak i zagranicznym. Kwestie związane $\mathrm{z}$ handlem zagranicznym rozpatrywał $\mathrm{m}$. in. poprzez pryzmat ziem polskich, zacofanych, jego zdaniem, pod względem cywilizacyjno-oświatowym i zagrożonych utratą tożsamości narodowej. Wzgląd na konieczność przyspieszenia postępu cywilizacyjnego tychże ziem determinował Supińskiego odstąpienie od liberalnego dogmatu nieingerencji władz w działalność gospodarczą na rzecz czasowego, przejściowego wprowadzenia protekcjonizmu celnego.

\section{Bibliografia}

Cieszkowski A., O kredycie i obiegu, Drukarnia: „Praca” J. Leitgeber, Poznań 1911.

Górski J., Polska myśl ekonomiczna a rozwój gospodarczy 1807-1830. Studia nad poczatkiem teorii zacofania gospodarczego, Państwowe Wydawnictwo Naukowe, Warszawa 1963.

Hołda-Róziewicz H., Jednostka w teorii socjologicznej Józefa Supińskiego, „Kwartalnik Historii Nauki i Techniki” 1994, R. 39, nr 1, s. 43-60.

Kłoskowska A., Socjologia w Polsce w drugiej połowie XIX w., „Studia i Materiały z Dziejów Nauki Polskiej" 1966, z. 9, s. 195-221.

Leońska L., Józefa Supińskiego teoria gospodarstwa społecznego, „Studia Socjologiczne" 1984, nr 1, s. 271-283.

Lityńska A., Idea narodowa i problem więzi społecznej w pracach Fryderyka Skarbka i Józefa Supińskiego, „Zeszyty Naukowe Akademii Ekonomicznej w Krakowie" 2003, nr 594, s. 101-111.

Pisma Józefa Supińskiego, t. 4, Gebethner i Wolff, Warszawa 1883.

Pisma Józefa Supińskiego, wydał J. Welichowski, t. 1-2, Drukarnia Zakładu Narodowego im. Ossolińskich, Lwów 1872.

Polska myśl filozoficzna i społeczna, pod red. A. Walickiego, t. 1, 1831-1863, Książka i Wiedza, Warszawa 1973.

Sorman G., Nowe bogactwo narodów, Kurs, Łódź-Warszawa 1989.

Torchalski R., Józef Supiński - polski teoretyk pracy, „Studia i Materiały z Dziejów Nauki Polskiej” 1973, z. 5, s. 258-274.

36 Tamże, s. 376-377. 